\title{
Metode Waris Perspektif Muhammad Shahrur Serta Upaya Rekonsiliasi dengan 'Urf
}

\author{
Masykurotus Syarifah, Ach.Maulana Elbe \\ Institut Agama Islam Nazhatut Thullab Sampang \\ Email: masykurohs@gmail.com \\ anankelbe@gmail.com
}

\begin{abstract}
:
In inheritance law, fiqh scholars have explained it in detail by referring to the Qur'an and al-Hadith and then setting it as an absolute law that cannot be tampered with anymore. Meanwhile, according to Muhammad Syahrur, Islamic inheritance law which is sourced from the verses of the Qur'an is the hudud provisions (limitations) set by Allah so that humans can ijtihad according to their respective circumstances within these limits. This research is a library research using a normative approach, namely conducting literature-analysis related to the object of research by emphasizing the truth and justice of an argument that is used as a legal basis. The writing of this thesis is descriptive-analytic, that is, the existing data are compiled, described and explained in detail and then analyzed. The analytical method of this research is Qualitative Content Analysis which is used to find and analyze a text or document to understand the meaning, significance and relevance of the text or document. The results of the study show that: first, the main priority in inheritance according to Muhammad Syahrur is a will, whether it is to the heir or not and exceeding one third or not. Inheritance law according to Syahrur is used only when the heirs consist of two types (male and female), if it is only of the same type then the inheritance is divided equally Second, in an effort to reconcile Muhammad Syahrur's inheritance with 'urf, one must believe that Muhammad Syahrur's inheritance is only one method in the distribution of inheritance, not a new law in Islamic inheritance. Then apply the conditions that apply in 'urfi inheritance such as the approval of the heirs in a will.
\end{abstract}

Keywords: Muhammad Syahrur, Waris, 'Urf

Dalam hukum kewarisan ulama fiqh sudah menjelaskannya secara rinci dengan berpedoman kepada al-Qur'an dan al-Hadits lalu menetapkannya sebagai hukum absolut yang tidak bisa diotakatik lagi. Sedangkan menurut Muhammad Syahrur hukum kewarisan Islam yang bersumber dari ayat-ayat al-Qur'an adalah ketetapan hudud (batasan-batasan) yang ditetapkan oleh Allah agar manusia bisa berijtihad sesuai keadaannya masing-masing dalam batasan-batasan tersebut. Penelitian ini merupakan penelitian kepustakaan (library research) dengan menggunakan pendekatan normatif yaitu melakukan analisis-literatur terkait dengan objek penelitian dengan menekankan kepada kebenaran dan keadilan suatu argumentasi yang dijadikan landasan hukum. Penulisan skripsi ini bersifat deskriptif-analitik, yaitu data-data yang ada disusun, digambarkan dan dijelaskan secara rinci lalu dianalisis. Metode analisis penelitian ini adalah Qualitative Content Analysis yang digunakan untuk menemukan dan menganalisis teks atau dokumen untuk memahami makna, signifikansi dan relevansi teks atau dokumen tersebut. Hasil penelitian menunjukkan bahwa: pertama, prioritas utama dalam waris menurut Muhammad Syahrur adalah wasiat, baik itu kepada ahli waris atau bukan dan melebihi sepertiga atau tidak. Hukum waris menurut Syahrur dipakai hanya ketika ahli waris terdiri dari dua jenis (laki-laki dan perempuan), apabila hanya sejenis maka harta waris dibagi sama rata Kedua, dalam upaya rekonsiliasi waris Muhammad Syahrur dengan 'urf maka harus menyakini bahwa waris Muhammad Syahrur hanya sekedar salah satu metode dalam pembagian waris, bukan hukum baru dalam kewarisan Islam. Lalu menerapkan syarat-syarat yang berlaku dalam waris 'urfi seperti persetujuan ahli waris dalam wasiat.

Kata Kunci: Muhammad Syahrur, Waris, 'Urf 


\section{Pendahuluan}

Hukum Islam dipahami sebagai hukum yang bersumber dari ajaran syariat Islam yaitu al-Qur'an dan al-Hadits, yang mengatur kehidupan manusia untuk mencapai kebahagiaan di dunia dan akhirat. Hukum Islam ialah sistem atau kaidah-kaidah yang didasarkan pada wahyu Allah dan Sunnah Rasul mengenai tingkah laku mukallaf yang diakui dan diyakini, yang mengikat bagi semua pemeluknya. ${ }^{1}$

Aturan agama Islam sangat luas dan lengkap, meliputi soal duniawi dan ukhrawi, mengatur soal pribadi, masyarakat, dan negara, bahkan mengatur hubungan mahkluk dengan Khaliknya. Oleh sebab itu di dalam Islam terdapat berbagai macam aturan yang telah dibukukan sebagai ilmu tersendiri, salah satu diantaranya yaitu ilmu fiqh. ${ }^{2}$ Di dalam syariat Islam masalah waris merupakan salah satu pembahasan ilmu fiqh yang terpenting. Waris merupakan harta kekayaan dan hutang yang ditinggalkan pewaris karena adanya peristiwa kematian. ${ }^{3}$ Persoalan tentang waris diatur oleh hukum waris yang merupakan segala peraturan hukum yang mengatur tentang beralihnya harta waris dari pewaris karena kematian kepada ahli waris atau orang yang ditunjuk.

Sebab-sebab kewarisan itu meliputi: Pertama, adanya hubungan kekerabatan atau nasab, seperti ayah, ibu, anak, cucu, saudara-saudara kandung, seayah, seibu, dan sebagainya; kedua adanya hubungan perkawinan yaitu suami istri, meskipun belum pernah berkumpul, atau bercerai, tetapi dalam masa iddah talak raj' $i$; ketiga, adanya hubungan wala' yaitu hubungan antara bekas budak dengan orang yang memerdekakannya, apabila budak itu tidak mempunyai ahli waris yang berhak menghabiskan seluruh harta warisan; dan keempat, tujuan Islam, yaitu bait al-mal yang menampung harta warisan orang yang tidak meninggalkan ahli waris sama sekali dengan sebab-sebab tersebut. ${ }^{4}$

Berangkat dari uraian yang telah dipaparkan diatas penulis tertarik untuk mengkaji lebih jauh penafsiran "waris" dalam pandangan Muhammad Syahrur dalam kitab tafsirnya Nahwa al-Ushul al-Jadidah Li al-Fiqhi al-Islami dan al-Kitab wa al-Qur'an.

Adapun alasan penulis memilih Muhammad Syahrur sebagai objek kajian lebih disebabkan karena pendapatnya dalam masalah ini cukup dinamis dan kontroversial. Penafsiran Syahrur sangatlah kontroversial jika dibanding dengan para penafsir pada umumnya. Tidak jarang para ulama tafsir menentang pemikirannya, bahkan yang lebih ekstrim menganggap penafsirannya adalah sesat. Akan tetapi dianggap dinamis dengan permasalahan kontemporer sehingga pada akhirmya akan menghasilkan suatu penafsiran yang relevan dengan kajian "waris" yang selalu menuntut keadilan sosial.

Muhammad Syahrur meyakini bahwa hukum itu tidak harus diberlakukan sebagai pemberlakuan secara literal teks-teks yang sudah diturunkan berabad-abad lalu pada dunia

\footnotetext{
${ }^{1}$ Eva Iryani, "Hukum Islam, Demokrasi dan Hak Asasi Manusia”,Jurnal Ilmiah Universitas Batanghari Jambi, Vol.17, No.2,(2017), hlm., 24.

http://dx.doi.org/10.33087/jiubj.v17i2.357

${ }^{2}$ Fiqh adalah salah satu bidang ilmu dalam syariat Islam yang secara khusus membahas persoalan hukum yang mengatur berbagai aspek kehidupan manusia, baik kehidupan pribadi, bermasyarakat maupun kehidupan manusia dengan Tuhannya yang berlandaskan dalil-dalil tafshiliyah. (Muhammad bin Ahmad bin Umar al-Syathiri, Syarh al-Yaqut al-Nafis)

${ }^{3}$ Amin Husein Nasution, Hukum Kewarisan, (Jakarta: PT. Raja Grafindo Persada, 2012), hlm. 50.

${ }^{4}$ Muhammad bin Salim bin Hafid al-'Alawi al-Husaini al-Tarimi, Takmilah Zubdatu al-Hadits (Bairut; Daar AlFikr, 2005), hlm 13.
} 
modern. Jika aplikasi literal semacam ini diterima, dapat dipastikan Islam akan kehilangan karakter keluwesan dan fleksibilitasnya. ${ }^{5}$

Perbedaan pendapat Muhammad Syahrur dengan ulama lain ini disebabkan oleh perbedaan alat dalam menentukan suatu hukum. Ulama lain dalam menafsirkan dan menjelaskan tentang "waris" (yang meliputi pengertian, rukun, syarat, pembagian harta warisan dan masalah-masalah yang timbul di dalamnya) pada umumnya berdalilkan tiga dalil dari al-Adillah Al-Syar'iyah; al-Qur'an, al-Hadits/al-Sunnah, dan Ijma'. Sedangkan Syahrur selain pemahamannya yang berbeda dalam menafsirkan al-Qur'an dan al-Hadits, Syahrur juga memiliki teori yang dinamakan teori hudud (batas) yang dikembangkan untuk mengetahui hukum Islam yang sebenarnya.

Bertitik tolak pada latar belakang yang telah diuraikan di atas, maka masalah dalam penelitian ini dapat dirumuskan sebagai berikut:Bagaimana konsep pemikiran Muhammad Syahrur tentang "waris"?Bagaimana upaya rekonsiliasi pemikiran Muhammad Syahrur tentang "waris" dengan "urf?

\section{Metode Penelitian}

Pendekatan yang digunakan penulis dalam penelitian ini adalah kualitatif. Penyusun melakukan analisis-literatur yang terkait dengan objek penelitian dengan menekankan kepada kebenaran dan keadilan suatu argumentasi yang dijadikan landasan hukum dengan menganalisis pemikiran Muhammad Syahrur tentang waris lalu merekonsiliasikannya dengan 'urf.

Sedangkan jenis penelitian ini sesuai dengan permasalahan yang diangkat dikategorikan sebagai penelitian kepustakaan (library research). Penelitian kepustakaan adalah salah satu bentuk metodologi penelitian yang menekankan pada pustaka sebagai suatu objek studi. Penelitian kepustakaan bukan berarti melakukan penelitian terhadap bukunya, akan tetapi lebih ditekankan kepada esensi dari yang terkandung pada buku tersebut mengingat berbagai pandangan seseorang maupun sekelompok orang selalu ada variasinya. ${ }^{6}$

Data yang diperoleh dalam penelitian ini dikumpulkan dan disusun secara sistematis kemudian dianalisis dengan menggunakan metode Qualitative Content Analysis. Dalam analisis ini semua data yang dianalisis berupa teks. Dalam hal ini berupa teks-teks pemikiran Muhammad Syahrur. Qualitative Content Analysis digunakan untuk menemukan, mengidentifikasi dan menganalisis teks atau dokumen untuk memahami makna, signifikansi dan relevansi teks atau dokumen tersebut.

\section{Pembahasan dan Hasil Penelitian}

Waris adalah proses pemindahan harta warisan dari orang yang meninggal kepada ahli waris yang jumlah, ukuran dan bagian harta warisan yang diterima telah ditentukan dalam proses wasiat, atau jika dalam wasiat tidak titentukan maka proses pembagian, ukuran dan jumlah harta warisan ditentukan berdasarkan mekanisme warisan. ${ }^{7}$ Dilihat dari pengertian yang ditawarkan oleh Syahrur tersebut menurut penulis secara umum tidak terdapat perbedaan dengan pengertian waris yang dikemukakan oleh para ulama ahli fiqh, Adapun perbedaan waris antara Syahrur dan ulama ahli fiqih itu terletak pada beberapa

\footnotetext{
${ }^{5}$ Muhammad Syahrur, Prinsip dan Dasar Hermeneutika Hukum Islam Kontemporer, terj. Sahiron Syamsudin, (Yogyakarta; eLSAQ Press, 2007) hlm. 8-9

${ }^{6}$ Mestika Zed, Metode Penelitian Kepustakaan, (Jakarta: Yayasan Obor Indonesia, 2018), hlm. 2

${ }^{7}$ Syahrur, Metodologi Fiqh, hlm. 334.
} 
permasalahan seperti :

1. Syahrur tidak membatasi ukuran wasiat $1 / 3$ sehingga ia mengatakan prioritas utama dalam masalah waris terletak pada wasiat, yaitu adakalanya pewaris sudah menentukan wasiat sebelum ia meninggal dengan menyerahkan seluruh hartanya kepada karib kerabatnya setelah ia meninggal dunia. ${ }^{8}$ Hal ini disebabkan karena Syahrur menolak dengan keras ilmu tentang nasikh-mansukh yang telah menghapus ayat wasiat dan menggantikannya dengan ayat waris.

2. Hukum waris menurut Syahrur berlaku hanya pada kondisi bertemunya dua jenis kelamin, laki-laki dan perempuan (misalnya ibu dan bapak, saudara laki-laki dan perempuan, anak laki-laki dan anak perempuan dan seterusnya). Adapun pada kondisi waris sejenis maka pembagian waris pada kondisi ini dilakukan secara merata. ${ }^{9}$

3. Terma walad (anak) dalam ayat-ayat waris memiliki arti ganda anak laki-laki dan perempuan. Adapun pendapat yang menyatakan bahwa laki-laki mengahalangi hak waris perempuan ataupun pendapat bahwa terma walad hanya berarti anak laki-laki saja, maka menurut Syahrur pendapat tersebut tidak harus untuk diikuti. ${ }^{10}$

4. Terkait masalah 'aul dan radd Syahrur menilai bahwa kewarisan adalah hukum yang tertutup, artinya tidak akan ada orang-orang yang akan memperoleh bagian selain yang disebut dalam ayat-ayat warisan. Juga tidak diperbolehkan memberlakukan kaidah radd maupun 'aul. Karena apabila memberlakukan radd maupun 'aul, seakan-akan kita tidak membagikan berdasarkan bagian yang telah ditetapkan oleh Allah dalam hukum-hukum dan batasan-batasan-Nya. ${ }^{11}$

5. Adapun terkait masalah pembagian waris, perbedaan yang sangat mencolok terletak pada pembahasan pembagian waris bagi anak laki-laki dan anak perempuan.

Dalam permasalahan bagian anak laki-laki dan perempuan, Syahrur melakukan interpretasi baru dengan hasil yang jauh berbeda dari ijtihad para ulama fiqh klasik. Hasil ijtihad Syahrur menunjukan bahwa ayat-ayat waris merupakan ayat yang mengatur keadilan pembagian harta berdasarkan kelompok (himpunan), bukan berdasarkan perolehan perseorangan. Maksudnya, keadilan yang ditawarkan dari alQur'an pada dasarnya adalah persamaan bagian waris terhadap kelompok himpunan laki-laki berbanding kelompok himpunan perempuan. ${ }^{12}$ Selain itu, menurutnya, dalam hal pembagian waris yang dijelaskan dalam ayat-ayat waris, terdapat dua jenis variabel, yaitu variabel pengikut (laki-laki) dan variabel pengubah (perempuan). Maksudnya, Syahrur menjadikan perempuan sebagai patokan dari semua. ${ }^{13}$ Lalu Muhammad Syahrur mencetuskan tiga teori batas khusus permasalahan ini yang sudah penulis uraikan dalam bab sebelumnya dalam penelitian ini.

Inilah beberapa pendapat Muhammad Syahrur tentang kewarisan Islam yang menjadikannya sebagai pembaharu dalam bidang keilmuan keislaman dan tokoh kontroversial dalam menafsirkan al-Qur'an dengan karya-karyanya yang selalu laku untuk dijadikan bahan penelitian oleh para ilmuan sampai saat ini.

Perbedaan pendapat Muhammad Syahrur dalam menafsirkan ayat-ayat waris dalam

\footnotetext{
${ }^{8}$ Ibid.

${ }^{9}$ Ibid., hlm. 417.

${ }^{10}$ Ibid., hlm. 339.

${ }^{11}$ Ibid., hlm. 417.

${ }^{12}$ Ibid., hlm. 336.

${ }^{13}$ Ibid., hlm. 340.
} 
al-Qur'an ini disebabkan adanya perbedaan dalam memahami konsep keadilan. Syahrur memahami konsep keadilan sebagai konsep sama rata tanpa melihat aspek lain seperti keadilan kewajiban nafkah, mahar dan lain sebagainya. ${ }^{14}$ Selain konsep keadilan, Syahrur juga berbeda pemahaman dalam memahami konsep dalil qath'i dan dhanni. Syahrur seakanakan tidak menerima keberadaan dalil qath' $i$ maupun dalil dhanni. Kecenderungan Syahrur terhadap relativitas dalam hal penafsiran al-Qur'an merupakan bukti akan hal tersebut. Pandangan ini akan cenderung membahayakan karena al-Qur'an bisa dibawa ke ranah kepentingan hawa nafsu selama bisa dicari pembenarannya dari al-Qur'an. ${ }^{15}$

Berdasarkan pemaparan Syahrur dalam buku keempatnya yang berjudul Nahwa alUsul al-Jadid li al-Fiqih al-Islami, penulis memiliki kesimpulan bahwa paling tidak terdapat dua macam metode inti yang digunakan oleh Syahrur, yaitu: Analisis Linguistik Semantik, dan Metaforik Saintifik, yang diadopsi dari ilmu-ilmu eksakta modern, seperti teknik analitik (al-Handasah al-tahliliyyah), matematika analitik (al-Tahlil al-riyadi), teori himpunan (Nazariyyah al-majmu'at), konsep variabel penutup (al-Tabi'l dependent variable), dan variabel perubah (al-Mutahawwil, independent variable) dalam matematika. ${ }^{16}$

Berkaitan dengan metode pertama, Syahrur secara konsisten mengikuti madzhab linguistik Abu 'Ali al-Farisi, terutama dalam hal penolakan terhadap adanya sinonimitas (taraduf) dan dalam hal komposisi (al-nazm) bahasa. Dalam menganalisis makna kata-kata dalam al-Tanzil, Syahrur menerapkan analisa Paradigma-Sintagmatik. Analisa Paradigmatik adalah sebuah analisa bahasa yang digunakan untuk memahami makna kata dengan cara membandingkan dengan kata-kata lain yang memiliki kemiripan makna atau justru memiliki makna yang bertentangan. Adapun analisa Sintagmatig adalah untuk mengetahui makna potensial mana yang secara rasional tepat untuk sebuah kata dengan melihat konteks tekstual di mana kata yang dimaksud digunakan, karena sangat dimungkinkan sebuah kata mengandung makna lebih dari satu (polisemi, musytarak al-ma'ani).

Sedangkan, terkait dengan metode kedua yakni penerapan ilmu eksakta modern, menurut Syahrur, adalah merupakan sebuah keniscayaan, mengingat al-Tanzil adalah wahyu terakhir untuk seluruh manusia yang Shalih li kulli zaman wa al-makan. Oleh karena itu, Syahrur juga menegaskan bahwa pembacaan yang dilakukan olehnya pun hanyalah merupakan penbacaan yang temporer tidak final. Karena orang yang mengklaim bahwa pemahaman terhadap al-Tanzil sebagai pemahaman yang mutlak, pada dasarnya ia hanyalah mengklaim sebagai sekutu Allah dalam hal pengetahuan. ${ }^{17}$ Dengan bahasa lain, bahwa semua bentuk penafsiran manusia adalah bersifat historis, ia hadir dari dan untuk ruang waktu tertentu. Sehingga penafsiran tersebut dapat berubah sesuai dengan kondisi dan waktu. $^{18}$

Kunci untuk memahami usaha Muhammad Syahur dalam melakukan defamiliarisasidemi membuka pemahaman-pemahaman yang baru dan kontemporer adalah metode Syahrur terhadap istilah yang terkait dengan al-Qur'an. Pertama-tama Syahrur mendekontruksi definisi umum dari terma tradisional dan mengungkapkannya sebagai definisi yang naif, tidak logis, bias dan rancu, dan akhirnya ia mengenalkan sebuah redefenisi terhadap istilah tersebut. Dalam karya-karyanya tidak ada satu pengertianpun

\footnotetext{
${ }^{14}$ Alda, "Waris Kesetaraan Gender", hlm., 15.

${ }^{15}$ Ibid.

${ }^{16}$ Syahrur,Nahwa Ushul, hlm. 235.

${ }^{17}$ Ibid., hlm. 139.

${ }^{18} \mathrm{Ibid}, \mathrm{hlm} .194$.
} 
Cabilah: Journal of Social Community

Terakreditasi Nasional SK No.14/E/KPT/2019
Print-ISSN: 2502-9649 Online-ISSN: 2503-3603

Vol.6 No.1 Juni 2021

yang dibiarkan tetap sebagaimana adanya. Dalam pembacaan Syahrur akan memporakporandakan paradigma kesarjanaan Islam yang selama ini tidak dipertanyakan lagi. Bahkan hadits yang dianggap sudah mapanpun. Contoh dari penolakan Syahrur terhadap hadis adalah penolakannya terhadap hadits yang diriwayatkan 'Abdullah Ibnu 'Abbas dari Nabi Saw, bahwa beliau bersabda "Tunaikan kewajiban faraidh bagi keluarga yang berhak. Adapun harta yang tersisa, maka berikanlah kepada keluarga pihak laki-laki”.

Setelah melakukan analisis terhadap hadits tersebut, Muhammad Syahrur menyimpulkan bahwa dalam hadis tersebut terdapat banyak hal yang meragukan dan hadits tersebut tidak layak dijadikan pegangan dalam pembagian harta warisan. ${ }^{19}$ Bagi Syahrur, hadis akan ditolak jika bertentangan dengan makna teks al-Quran. Sehingga tidak mengherankan dimana istilah-istilah dan konsep-konsep barunya sulit dicerna bagi para sarjana tradisioal.

Salah satu kontribusi baru dalam kajian fiqh kontemporer yang disumbangkan oleh Syahrur adalah gagasannya tentang teori batas hukum. Dalam karyanya yang sangat kontroversial, al-Kitab wa al-Qur'an: Qira'ah Muashirah, Syahrur menegaskan bahwa teori batasmerupakan salah satu pendekatan dalam berijtihad, yang digunakan untuk mengkaji ayat-ayat muhkamat (ayat-ayat yang berisi pesan hukum) dalam al-Qur'an. Menurut Wael B Hallaq, teori limit Syahrur telah mengatasi kebuntuan epistimologis yang menimpa karyakarya sebelumnya. ${ }^{20}$

Namun paling tidak teori batas yang digagas oleh Muhammad Syahrur memberikan empat kontribusi dalam pengayaan fiqh.Pertama, dengan teori batas, Syahrur telah berhasil melakukan pergeseran paradigma yang sangat fundamental di bidang fiqh. Selama ini pengertian hudud dipahami para ahli fiqh sebagai ayat-ayat dan hadis-hadis yang berisi ketentuan sanksi hukum (al-uqubat) yang tidak boleh ditambah atau dikurangi dari ketentuan yang tertulis, seperti hukum potong tangan bagi pencuri, cambuk 100 kali bagi pelaku zina, dan lain sebagainya. Berbeda dengan itu, teori batas (teori hudud) yang ditawarkan Syahrur cenderung bersifat dinamis-kontekstual, dan tidak hanya menyangkut masalah sanksi hukum (al-uqubat). Teori batas Syahrur juga menyangkut aturan-aturan hukum lainnya, seperti soal libasul mar'ah(pakaian perempuan), ta'addudu alzawj(poligami), pembagian warisan, riba dan lain sebagainya. ${ }^{21}$

Kedua, teori batas Syahrur menawarkan ketentuan batas maksimum (al-hadd al-a'la) dan batas minimun (al-hadd al-adna) dalam menjalankan hukum-hukum Allah. Artinya, hukum-hukum Allah diposisikan bersifat elastis, sepanjang berada diantara batas maksimum dan batas minimum yang telah ditentukan. Wilayah ijtihad manusia, menurut Syahrur berada diantara batas minimum dan maksimum tadi. Elastisitas dan fleksibilitas hukum Allah dapat digambarkan seperti posisi seorang pemain bola yang bebas bermain bola, asalkan tetap berada pada garis-garis lapangan yang telah ada. Pendek kata, selagi ijtihad masih berada dalam wilayah hududullah (batas-batas hukum Allah), maka dia tidak dapat dianggap keluar dari hukum Allah. Contoh dalam kewarisan, ketentuan pembagian 2:1 antara laki-laki dan perempuan, dimana dua bagian merupakan batas maksimum bagi laki-laki dan satu adalah batas minimum bagi anak perempuan.

Ketiga, dengan teori batasnya, Syahrur telah melakukan dekontruksi dan rekontruksi terhadap metodologi ijtihad hukum, utamanya terhadap ayat- ayat hudud yang selama ini

\footnotetext{
${ }^{19}$ Syahrur, Metodologi Fiqh, hlm., 417.

${ }^{20}$ Syahrur, Prinsip dan Dasar. hlm., 14.

${ }^{21}$ Sunardi Panjaitan, Teori Batas Hukum Islam, hlm. 70.
} 
diklaim sebagai ayat-ayat muhkamat yang bersifat pasti dan hanya mengandung penafsiran tunggal. Bagi Syahrur, ayat-ayat muhkamat juga dapat dipahami, bahkan bagi Syahrur dipahami secara pluralistik, sebab makna suatu ayat itu dapat berkembang, tidak harus sesuai dengan makna (pengertian) ketika ayat itu turun. Walhasil, penafsiran suatu ayat sesungguhnya bersifat relatif dan nisbi, sesuai dengan perkembangan zaman. Dengan kata lain melalui teori batas, Syahrur ingin melakukan pembacaan ayat-ayat muhkamat secara produktif dan prospektif (qira'ah muntijah) bukan pembacaan yang bersifat repetitive dan restrospektif (qira'ah mutakarrirah). ${ }^{22}$

Keempat, dengan teori batas, Syahrur ingin membuktikan bahwa ajaran Islam benarbenar ajaran yang relevan untuk tiap ruang dan waktu. Syahrur berasumsi, kelebihan risalah Islam adalah bahwa di dalamnya terkandung dua aspek gerak, yaitu gerak konstan/lurus (istiqamah) serta gerak dinamis/lentur (hanifiyyah). Nah, sifat kelenturan Islam ini berada dalam bingkai teori batas yang oleh Syahrur dipahami sebagai the bounds or restriction that God has placed on men freedom of action (batasan yang telah ditempatkan oleh Tuhan pada wilayah kebebasan manusia). Kerangka analisis teori batas yang berbasis dua karakter utama ajaran Islam ini (aspek yang konstan dan lentur) akan membuat Islam tetap survive sepanjang zaman. ${ }^{23}$

Berkenaan dengan pembacaan al-Qur'an secara tekstual dan kontekstual, Syahrur adalah tokoh pemikiran Islam yang memadukan kedua kategori tersebut. Perpaduan itu, salah satunya di lakukan Syahrur melalui teori batasnya. Teori batas yang di gagas Syahrur selalu merujuk kepada teks al-Kitab, untuk dikontektualisasikan dalam konteks kekinian atau modern. Pendekatan tekstual yang dilakukan oleh Syahrur melalui teori batasnya, sangat berbeda dengan logikan maenstream yang selama ini berkembang di kalangan kaum tekstualis, khususnya dengan nash al-Qur'an yang berkaitan dengan masalah-masalah hukum. Bagi Shahrur, ayat-ayat hukum dalam al-Qur'an bersifat hududiyyah, dengan pengertian Allah satu-satunya hakim yang berhak menentukan batas-batas hukum, tetapi manusia diberikan kebebasan berijtihad dalam menentukan batas-batas hukum Allah sesuai dengan kondisi tertentu.

Akan tetapi teori ini harus dianalisis secara mendalam terutama dalam implementasinya dalam hukum waris yang sudah di tentukan pembagiannya oleh Allah. Apakah teori ini mampu menyelesaikan permasalahan yang ada dalam persoalan pembagian waris atau bahkan menambah masalah dalam hukum waris itu sendiri.

Secara umum teori batas Syahrur ini memang perlu diapresiasi dalam perkembangan kajian fiqh kontemporer, namun pada sisi tertentu, teori ini haruslah dikaji lebih mendalam apakah layak untuk dijadikan alternatif penyelesaian dalam permasalahan-permasalahan hukum Islam terutama dalam permasalahan waris.

Pertama, teori batas lahir dari metode linguistik yang digunakan oleh Syahrur dalam mengkaji ayat-ayat Tanzil al-Hakim, terutama dalam kajian dua istilah yaitu al-hanif dan alistiqamah. Sebagaimana disebutkan oleh Dr. Ja'far Dikk al-Bab dalam pengantar bukunya Muhammad Syahrur, bahwa Muhammad Syahrur adalah seorang ahli bahasa disamping beliau juga seorang insinyur teknik. Metode linguistik Muhammad Syahrur bersumber dari teori linguistik Ibn Jinni dan Imam al-Jurjani. Syahrur merupakan tokoh intelektual yang menjadikan linguistik sebagai dasar kajiannya. Sehingga teks menjadi lebih hidup dalam

${ }^{22}$ Ibid., hlm. 71.

${ }^{23}$ Ibid., hlm. 72. 
kajian Syahrur. ${ }^{24}$ Pada tataran ini, teks bisa berjalan berkelindan dengan kondisi sosiohistoris masyarakat dalam artian yang menjadi patokan utama adalah kondisi sosio-historis masyarakat yang cenderung berubah seiap saat dan teks harus ditafsirkan sesuai perubahan sosio-historis masyarakat tersebut. Syahrur terlalu menjadikan teks sebagai pijakannya sehingga yang terjadi adalah teks menjadi relatif tergantung penafsiran teks serta tergantung kepada para penafsir. Akibat hukumnya adalah tidak adanya kejelasan dalam suatu masalah hukum. Disinilah problematika hermeneutika yang dibangun oleh Syahrur atau mungkin para hermeneut-hermeneut lainnya yang menjadikan hermeneutika (kajian teks) dalam menafsirkan ayat-ayat al-Qur'an.

Kedua, Syahrur dalam beberapa hal tidak menerima hal-hal yang telah menjadi pemahaman umum masyarakat Islam, misalnya pandangannya terhadap posisi Nabi yang dianggap bukan sebagai sumber hukum, melainkan memposisikan Nabi sebagai mufassirpertama yang menafsirkan al-Qur'an yang sesuai dengan kondisi sosio-historis masyarakat Madinah pada waktu itu. Hukum yang di tetapkan oleh Nabi, bagi Muhammad Syahrur hanya bisa di praktekkan pada masa itu, dan bisa diterapkan pada kondisi saat ini, apabila ketentuan itu sesuai dengan kondisi pada saat ini. Artinya, kondisi sosio-historis masyarakat harus menjadi patokan dasar dalam penetapan hukum. Maka, bagi Syahrur teks harus ditafsir ulang sesuai dengan kondisi masyarakat saat ini. Redaksi teks memang tidak berubah, tapi tafsirannya harus disesuaikan dengan kondisi saat ini. Yang menjadi dasar atau pedoman pada umat Islam dari Nabi dalam pandangan Syahrur hanyalah hal-hal yang bersifat ritualitas agama, seperti praktek sholat, puasa dan ibadah haji. Sedangkan ayat-ayat muhkamat yang dalam pandangan para ulama tidak bisa di tafsir ulang, bagi Syahrur bukanlah tafsir tunggal yang harus dituruti. Baginya, ayat-ayat muhkamat yang bagi umat Islam sudah jelas maksudnya, seperti masalah waris perlu ditinjau ulang bila tidak sesuai dengan kondisi masyarakat.

Ketiga, dalam permasalahan waris, teori batas yang digagas Syahrur tidak sempurna, hanya menyentuh permasalahan-permasalahan yang muncul antara anak laki-laki dan anak perempuan. Sedangkan masalah-masalah yang menyangkut paman, ibu, kakek, nenek, ayah dan yang lain tidak mendapat bagian. Paradigma yang timbul adalah ahli waris yang ada hanyalah anak laki-laki dan anak perempuan semata.

\section{Upaya Rekonsiliasi Waris Muhammad Syahrur Dengan 'Urf}

Rekonsiliasiadalahperbuatanmemulihkanhubunganpadakeadaansemula, atauperbuatanmenyelesaikanperbedaan. Jadi maksud dari upaya rekonsiliasi waris Muhammad Syahrur dengan 'urf adalah sebuah upaya menyelesaikan permasalahanpermasalahan didalam waris perspektif Muhammad Syahrur dengan panduan waris 'urfi yang ada di Indonesia.

Adapun waris 'urfi adalah sistem pembagian harta warisan kepada ahli waris setelah meninggalnya pewaris dengan tata cara adat atau kebiasaan dalam suatu golongan masyarakat tertentu, yang pembahasannya sudah dibahas dalam bab sebelum bab ini. Jadi dalam sub bab ini penulis akan berupaya (sesuai kemampuan penulis) untuk menyelesaikan permasalahan-permasalahan yang penulis temukan dalam waris Muhammad Syahrur dengan berpegang kepada waris 'urfi sebagai pedoman (alat menyelesaikan masalah).

Sebelum masuk kepada upaya rekonsiliasi waris Muhammad Syahrur dengan 'urf, dari analisis di atas maka dapat disimpulkan perbandingan antara waris Muhammad Syahrur

\footnotetext{
${ }^{24}$ Muhammad Syahrur, Nahw Ushul, hlm. 5.
} 
dengan waris 'urfi yang di Indonesia. Diantaranya sebegai berikut:

\section{Persamaan}

Keduanya merupakan suatu pembaharuan hukum Islam dalam masalah pembagian warisan.

Berasaskan keadilan bersama menurut masing-masing.

Diterapakan dalam masyarakat baik secara langsung atau tidak langsung.

Mengutamakan wasiat dalam pembagian waris meskipun melebihi sepertiga dari harta warisan.

Tidak memberlakukan 'aul dan radd

Lebih terfokus kepada permasalahan pembagian warisan antara anak laki-laki dan anak perempuan.

Boleh berwasiat kepada ahli waris.

\begin{tabular}{|c|c|}
\hline \multicolumn{2}{|c|}{ PERBEDAAN } \\
\hline Muhammad Syahrur & Waris 'Urfi \\
\hline $\begin{array}{l}\text { Murnimengandungpembaharuanpe } \\
\text { mikiran hukum Islam } \\
\text { terkaithukum kewarisan Islam }\end{array}$ & $\begin{array}{l}\text { Sebagianmengalami pembaharuan } \\
\text { hukum Islam terkait hukum } \\
\text { kewarisan Islam }\end{array}$ \\
\hline $\begin{array}{l}\text { Dianggap sebagai hukum baru } \\
\text { waris yang dapat meminimalisir } \\
\text { permasalahan yang ada pada } \\
\text { hukum waris sebelumnya }\end{array}$ & $\begin{array}{l}\text { Hanya sebuah metode/cara dalam } \\
\text { pembagian harta warisan untuk } \\
\text { mencegah perselisihan keluarga. }\end{array}$ \\
\hline $\begin{array}{l}\text { Keadilan pembagian harta yang } \\
\text { dimaksud berdasarkan kelompok } \\
\text { (himpunan) }\end{array}$ & Keadilan perseorangan (i \\
\hline $\begin{array}{l}\text { Wasiat bisa melebihi sepertiga } \\
\text { bagian tanpa syarat adanya izin } \\
\text { ahli waris }\end{array}$ & Harus ada izin ahli waris \\
\hline $\begin{array}{l}\text { Boleh berwasiat kepada ahli waris } \\
\text { tanpa persetujuan dari ahli waris } \\
\text { yang lain. }\end{array}$ & $\begin{array}{l}\text { Harus dengan persetujuan ahli } \\
\text { waris yang lain }\end{array}$ \\
\hline $\begin{array}{ll}\text { Pembagian bergantung } & \text { kepada } \\
\text { jumlahperempuan. } & \\
\text { Perempuanadalah } & \text { variabel } \\
\text { pengubah, sedangkan } & \text { laki-laki } \\
\text { adalahvariabel pengikut. } & \\
\end{array}$ & $\begin{array}{l}\text { Terkadang melihat kondisi masing- } \\
\text { masing ahli waris. } \\
\text { Terkadang dibagi sama rata. }\end{array}$ \\
\hline
\end{tabular}

Dari analisis perbendingan di atas maka dapat disimpulkan upaya rekonsiliasi waris dalam perspektif Muhammad Syahrur dengan 'urf adalah sebagai berikut :

1. Harus meyakini bahwa pembagian waris menurut ulama fiqh adalah asal hukum pembagian waris. Adapun waris Muhammad Syahrur adalah salah satu dari beberapa metode atau cara pembagian waris yang mengutamakan keadilan bersama dan mencegah perselisihan keluarga.

2. Diberlakukannya persyaratan dalam waris 'urfi baik menggunakan wasiat atau akad as- 
shulhu, seperti persetujuan ahli waris dalam berwasiat melebihi sepertiga bagian baik kepada ahli waris atau kerabat yang lain.

Demikian penjelesan waris dalam perspektif Muhammad Syahrur serta upaya rekonsiliasinya dengan 'urf yang bisa penulis sajikan dengan keterbatasan dan kemampuan penulis. Wallahu a'lam bi as-showab.

\section{Penutup}

Dari penelitian yang sudah penulis paparkan pada beberapa bab sebelumnya. Terkait dengan penjelasan tentang rumusan masalah yang menjadi dasar dari penelitian ini. Maka penulis akan memberikan poin-poin inti dalam penelitian ini, sebagaimana berikut:

1. Waris dalam perspektif Muhammad Syahrur

Waris menurut Syahrur adalah proses pemindahan harta yang dimiliki seseorang yang sudah meninggal kepada pihak penerima yang jumlah dan ukuran bagian (nasib) yang diterimanya telah ditentukan dalam mekanisme wasiat, atau jika tidak ada wasiat, maka penentuannya ditentukan dalam mekanisme pembagian warisan. Prioritas utama dalam masalah ini menurut Muhammad Syahrur terletak pada wasiat, baik itu wasiat kepada ahli waris atau kerabat lainnya, dan melebihi sepertiga bagian atau tidak.

Muhammad Syahrur menafsirkan ayat-ayat waris bukan sebagai ketetapan yang absolut melainkan sebagai huddud (batasan-batasan) yang ditetapkan oleh Allah dalam al-Qur'an yang ia simpulkan dengan teori batas yang ia buat. Teori batas yang dimaksudkan di sini adalah batas maksimal danminimal datang secara bersamaan, namun tidak menyatu dalam satu garis. Hal ini berdasarkan al-Qur'an surat an-Nisa' ayat 13 yang berbunyi tilka hududallah (Hukum-hukum tersebut itu adalah ketentuanketentuan dari Allah).

Adapun dalam pembagian harta warisan, Syahrur berpendapat bahwa keadilan yang ditetapkan oleh Allah adalah keadilan secara kelompok (himpunan) bukan keadilan perseorangan (individual). Dan juga hukum waris menurut Syahrur berlaku hanya pada kondisi bertemunya dua jenis kelamin, laki-laki dan perempuan. Adapun pada kondisi waris sejenis maka dilakukan secara merata.

2. Upaya rekonsiliasi waris Muhammad Syahrur dengan 'urf

Upaya rekonsiliasi waris dalam perspektif Muhammad Syahrur dengan 'urf yang dilakukan penulis adalah sebagai berikut :

a. Harus meyakini bahwa pembagian waris menurut ulama fiqh adalah asal hukum pembagian waris. Adapun waris Muhammad Syahrur adalah salah satu dari beberapa metode atau cara pembagian waris yang mengutamakan keadilan bersama dan mencegah perselisihan keluarga.

b. Harus diberlakukannya persyaratan dalam waris 'urfi baik menggunakan wasiat atau akad as-shulhu, seperti persetujuan ahli waris dalam berwasiat melebihi sepertiga bagian baik kepada ahli waris atau kerabat yang lain. 
Cabilah: Journal of Social Community

Terakreditasi Nasional SK No.14/E/KPT/2019
Print-ISSN: 2502-9649 Online-ISSN: 2503-3603

Vol.6 No.1 Juni 2021

\section{Daftar Pustaka}

Abu Sunah,Ahmad Fahmi.al- 'Urf wa al-'Adah fi Ra'yi al-Fuqaha. Mesir: Maktabah alAzhar, 1947.

Al-'Alawy, Muhammad Salim. Takmilatu Zubdati al-Hadits Fi Fiqhi al-Mawarits. Bairut: Daar al-Fikr, 2005.

Al-Bukhari, Muhammad bin Isma'il.Shahih al-Bukhari. Bairut: Daar Ibnu Katsir, 2002.

Al-Hajjaj, Muslim. Shahih Muslim. Riyadh: Dar al-Mughni, 1998.

Al-Tirmidzi,Abu Isa Muhammad.al-Jami' al-Shohih Sunan al-Tirmidzi. Riyadh; Dar alMughni, 1978.

Al-Zuhaili, Wahbah.Fiqh al-Islam wa Adillatuh.Bairut: Daar al-Fikr, 2004.

---------. Ushul al-Fiqh al-Islami. Damaskus: Dar al-Fikr, 1986.

As-Saayis, Muhammad Ali, Abdul Latif as-Subky dan Muhammad Ibrahim. Tafsiru Ayatu al-Ahkam. Bairut: Daar Ibnu Katsir, 2007.

As-Syathiry, Muhammad Ahmad, Syarhu al-Yaqut an-Nafis. Bairut: Daar al-Minhaaj, 2007.

Hambal, Ahmad bin Muhammad.Musnad Ahmad Bin Hambal Jilid V. Beirut: Dar al-Kutub, 2000.

Kementrian Agama RI, Al-Qur'an dan Terjemahannya.PT. Macananjaya Cemerlang, 2015.

Khallaf, Abdul Wahab. Ilmu Ushul al-Fiqh. Jakarta: Daar al-Kutub al-Islamiyah. 2010.

--------, Mashadir al-Tashri ‘ al-Islami fi Ma Laysa Nash fih. Kuwait: Dar al- Qalam, 1972.

Mardani, Hukum Kewarisan Islam di Indonesia. Jakarta: PT. Raja Grafindo Persada, 2014.

Nasution, Amin Husein, Hukum Kewarisan, Jakarta: PT. Raja Grafindo Persada, 2012.

Phoenix,Tim Pustaka.KamusBesar Bahasa Indonesia. Jakarta: Pustaka Phoenix, 2007.

Rofiq, Ahmad.Fiqh Mawaris, Jakarta; PT Raja Grafindo Persada, 2012.

---------. Hukum Perdata Islam di Indonesia. Jakarta: PT Raja Grafindo Persada, 2013.

Sajja, R dan Iqbal Taufik.Dinamika Hukum Islam, Yogyakarta: Deepublish, 2016.

Suparman, Eman.Hukum Waris Indonesia Dalam Perspektif Islam Adat dan BW. Bandung: Refiks Aditama, 2018. 
Syahrur, Muhammad.al-Islam wa al-Iman; Manzhumah al-Qiyam Terj. Iman dan Islam. oleh M. Zaid Su'di. Yogyakarta: IRCiSoD, 2015.

------. al-Kitab wa al-Qur'an. Damaskus: al-Ahaaly, 1992.

-------.Nahw Usul Jadidah li al-Fiqh al-Islami, Terj. Metodologi Fiqh Islam Kontemporer oleh Sahiron Syamsuddin dan Burhanudin. Yogyakarta: eLSAQ Press, 2004.

--------.Prinsip dan Dasar Hermeneutika Hukum Islam Kontemporer. Yogyakarta: eLSAQ Press, 2007.

Syarifuddin, Amir. Ushul Fiqh. Jilid II. Jakarta: Kencana Prenada Media Group, 2014.

Undang-Undang R.I. Nomor 1 Tahun 1974 Tentang Perkawinan dan Kompilasi Hukum Islam. Bandung: Citra Umbara, 2017.

Utsman, Rachmadi. Hukum Kewarisan Islam; Dalam Dimensi Kompilasi Hukum Islam. Banjarmasin: Mandar Maju, 2009.

Zed,Mestika.Metodologi Kepustakaan. Jakarta: Yayasan Obor Indonesia, 2018.

Andi, Azhari.Reinterpretasi Sunnah ; Studi Pemikiran Muhammad Syahrur Terhadap Sunnah. Jurnal Living Hadis. UIN Sunan Kalijaga, Yogyakarta vol. 1, no. 1, 2016. http://ejournal.uin-suka.ac.id/ushuluddin/Living/article/view/1069

Idhom, Minaul. Bagian Waris Laki-Laki dan Perempuan Dalam Islam Perspektif Muhammad Syahrur dan Muhammad Quraish Shihab. Skripsi. IAIN Sunan Kalijaga, Yogyakarta, 2016. http://digilib.uin-suka.ac.id/23170/1/12360047_BAB-I_IV-atau-V_DAFTARPUSTAKA.pdf

Iryani, Eva. Hukum Islam, Demokrasi dan Hak Asasi Manusia. Jurnal Ilmiah Universitas Batanghari Jambi, Vol. 17 No. 2, 2017. http://dx.doi.org/10.33087/jiubj.v17i2.357

Muslimah,NinikQori'atul.KonsepPembagianWarisMenurut Muhammad Syahrur dan KompilasiHukum Islam. Skripsi. IAIN Ponorogo, 2017. http://etheses.iainponorogo.ac.id/2184/1/Ninik\%20Qori\%27atul\%20Muslimah.pdf

Nawawi, M Anwar. Hukum Kewarisan Dalam Perspektif Muhammad Syahrur : Studi Kritis Terhadap Bagian Ahli Waris. Tesis. IAIN Raden Intan, Lampung, 2016. http://repository.radenintan.ac.id/id/eprint/83

Panjaitan, Sunardi. Teori Batas Hukum Islam : Studi Terhadap Pemikiran Muhammad Syahrur Dalam Waris. Skripsi. UIN Syarif Hidayatullah, Jakarta, 2008. 
https://adoc.tips/teori-batas-hukum-islam-studi-terhadap-pemikiran-muhammad-sh.html Sucipto, "Urf SebagaiMetode Dan SumberPenemuanHukum Islam" Jurnal ASAS IAIN Raden Intan Lampung, Vol. 7, No. 1 (2015). http://ejournal.radenintan.ac.id/index.php/asas/article/view/1376

Ulfiyati, Nur Shofa. Pemikiran Muhammad Syahrur: Pembacaan Muhammad Syahrur terhadap Teks-Teks Keagamaan. Jurnal Et-Tijarie STAI Al-Yasini Pasuruan, Vol. 5, No. 1, 2018.

https://journal.trunojoyo.ac.id/ettijarie/article/view/4597/3208

Yudha, Alda Kartika. Waris Kesetaraan Gender : Komparasi Perspektif Wahbah az-Zuhaily dan Muhammad Syahrur. Muwazah Jurnal Kajian Gender, Vol. 11, No. 1, 2019. http://e-journal.iainpekalongan.ac.id/index.php/Muwazah/article/view/1892/1538

Yusuf, Muhammad. Hermeneutika Al-Qur'an Muhammad Syahrur. Jurnal Diskursus Islam STAI Al-Furqon Makasar, Vol. 2, No. 1, 2014.

http://journal.uin-alauddin.ac.id/index.php/diskursus_islam/article/view/6509/5327

Zahara,Rana Annisa.KonsepDua Banding Satu DalamPembagianHartaWarisanStudiPerbandinganJumhurUlamadan Muhammad Syahrur. Skripsi. UIN Ar-Raniry, Darussalam, Banda Aceh, 2017. https://repository.arraniry.ac.id/id/eprint/3502/3/SKRIPSI\%20RANA\%20ANNISA\%20ZAHARA.pdf 